\title{
Human Trafficking: A Modern Day Slavery in Nigeria
}

\author{
Folashade B. Okeshola \\ Deparment of Sociology \\ Ahmadu Bello University, Zaria \\ Nigeria \\ Adebimpe A. Adenugba \\ Department of Sociology \\ University of Ibadan \\ Nigeria
}

\begin{abstract}
Human trafficking in Nigeria has assumed unimaginable dimension in the last two decades due to several factors which include globalization, economic recession, poverty, conflicts, weak legal system, and lack of adequate legislation and of political will. Human trafficking is an organised crime. It is a modern form of slavery. The two weapons used by traffickers to get their victims are deception and through force. Human trafficking has continued to strive in Nigeria because of collusion among security, immigration, embassy, airline officials and traffickers. Human trafficking had become a major source of concern to all societies in recent time. Human trafficking has put Nigeria on the map of the notorious. In view of the above, we recommend that the Nigerian government should address the issue of massive unemployment and poverty in Nigeria as well as create enabling environments for entrepreneurship for the citizens.
\end{abstract}

Keywords: Deception, forced labour, exploitation, trafficking, slavery

\subsection{Introduction}

Human trafficking is a crime. This crime has been on for some time, without much government notice or attention being drawn to the issue. The first worthwhile attention was drawn to the idea of human trafficking by Mrs.TitiAtiku, the wife of the then vice president of Nigeria. This subsequently led to the establishment of her pet project WOTCLEF. In furtherance of her dream and to redeem the image of Nigeria in general and dignity of women in particular, a bill was proposed to set up an agency to be given specific mandate to tackle the problem of human trafficking in Nigeria. The agency is known as the National Agency for Prohibition in Persons and Other Related Matters (NAPTIP). This Agency is charged with the responsibility of monitoring, arresting and prosecution of human traffickers as well as rehabilitation of victims of human trafficking. Underlying the heinous crime of trafficking in humans is the fact that globalization has created inequalities and inequities resulting in the migration of the poor to the rich regions of the world. Accompanying this also is the related dimension of security of states and individuals, significantly jeopardized by activities of international criminal gangs or networks of crime specializing in money laundering, arms trafficking, advance fee fraud and human trafficking (Ogwu, 2002). An increasing number of African migrants got drowned in the Mediterranean seas in their bid to cross to Europe. Many met their deaths in the deserts of North Africa. There is also massive deportation of undocumented or illegal migrants' mostly Nigerian women and girls.

The Trafficking in Persons (Prohibition) Law Enforcement and Administration Act (2003), defines trafficking as all acts and attempted acts involved in the recruitment, transportation within or across Nigeria borders, purchases, sales, transfer, receipt or harbouring of a person involving the use of deception, coercion or debt bondage for the purpose of placing or holding the persons, whether for or not involuntary servitude (domestic, sexual or reproductive) in forced or bonded labour, or in slavery-like conditions. Human trafficking according to Article 3(a) of the United Nations Palemo Protocol, is defined as "recruitment, transportation, transfer, harbouring, or receipt of persons, by means of threat or use of force, other forms of coercion, of abduction, of fraud, of deception, of the abuse of power or of a position of vulnerability or of giving or receiving of payments or benefits to achieve the consent of a person having control over another person for the purpose of exploitation". 


\subsection{Trends in Human Trafficking}

Human trafficking is a modern form of slavery. It is an illegal business and a social problem. Human trafficking is a social problem because it affects many people. It affects different categories of people. It is a social problem because of the magnitude, the trend and pattern it has taken over the years. This business has unleashed untold hardship on victims who are mostly women and children. For most crimes to succeed there must be a giver and a taker. For the crime of trafficking to succeed, there must be people who aid or facilitate the movement and transportation of victims to a defined destination. There must also be a group who abets the crime, and who are the receiver.

Human trafficking is an organised crime. Many people are involved. It is a chain or continuum, with people in the crime performing specific tasks. In this organised crime there are recruiters. These are people who go to villages to deceive young girls and boys through their parents. They give the impression to parents of assisting their relations for a better education, employment without the full knowledge of what await their children. Recruiters include sisters, brothers, in-laws, driver, business men and women, law enforcement officers, etc. The would-be victims move from one stage to another until they get to their final destinations where these young girls and boys are distributed to madams and "ogas" who need their services. We should bear in mind that the two weapons used by traffickers to get their victims are deception and through force. Human trafficking is a crime. Those who engaged in trafficking persons are often friends, relations, neighbour and familiar people to victims. Human trafficking is an organised crime. It has a chain of syndicate. In this organised crime we have the:

- Sponsors, financial and facilitators,

- There are madams or bosses, supervisors, accomplices or collaborators, aiders and abetters,

- Victims or persons who are trafficked and exploited (Okeshola, 2007).

Human trafficking has continued to strive in Nigeria because of collusion among security, immigration, embassy and airline officials and traffickers. These officials often take bribes in exchange for facilitating smooth passage across the borders for traffickers and their victims (Musikilu, 2008).

\subsection{Contributory Factors to Human Trafficking}

The practice of entrusting poor children to more affluent friends or relatives may create vulnerability. Some parents sell their children, not just for the money, but also in the hope that their children will escape a situation of chronic poverty and move to a place where they will have a better life and more opportunities (Adepelumi, 2015). We should bear in mind that trafficking in persons can take four (4) different forms within the country, we have:

- Rural-Urban Trafficking: This is where victims move from rural areas to urban areas.

- Urban-Rural Trafficking: This is where victims move from urban area to rural areas. People in this category are usually trafficked for farming purpose.

- Rural-Rural Trafficking: This is a situation where traffickers move victims from one rural area to another.

- Urban-Urban Trafficking: This is where traffickers move victims from one urban area to another (Okeshola, 2007).

Within Nigeria, women and girls are trafficked primarily for domestic servitude and commercial sexual exploitation. Boys are trafficked for forced labour in street vending, agriculture, mining, stone quarries and as domestic servants. There is high demand for child workers at the household level, agricultural, construction, quarries and brass melting mostly in the informal sector (Adepelumi, 2015).

Human trafficking refers to the illegal and immoral buying and selling of human beings as commodities to meet global demands for commercial sexual slavery or forced labour. Human trafficking, unfortunately, is one of the most flourishing and profitable criminal industries of the world. It has sometimes direct and sometimes indirect connections with the illegal arms and illicit drug trade industries. Commercial sexual exploitation and sex slavery form the major chunk of demand that drives human trafficking numbers higher with forced labour constituting a proportionately smaller ratio of the demand for human beings as commodities (Shukla, 2011).

\subsection{Poverty}

Poverty is the principle driving force behind this trade, propelling vulnerable people into the hands of traffickers, who belong to both small-scale, local enterprises with extensive criminal networks and to large scale multicommodity businesses. 
Destinations for trafficked Nigerians include the neighboring West African countries (Côte d'Ivoire, Mali, Benin, Equatorial Guinea, Cameroon, Gabon and Guinea), European countries (Italy, Belgium, Spain, the Netherlands, Germany and the United Kingdom), North Africa (Libya, Algeria and Morocco) and Middle Eastern countries (Saudi Arabia). Recently, South America has also become a point of destination for trafficked persons, particularly Venezuela. Primarily women and girls, but boys are also trafficked for purposes of sexual exploitation, forced labour and organ harvesting. (UNESCO,2006).

Poverty is widespread in Nigeria. ILO/IPEC report shows that 8 million Nigerian children engaged in exploitative child labour and $40 \%$ of Nigerian street children and hawkers are trafficked children due to poverty. The report showed that the desire of Nigerian potential victims to migrate is exploited by offenders to recruit and gain initial control or cooperation, only to be replaced by more coercive measures once the victims have been moved to another state or region of the country, which may not always be the one to which they had intended to migrate.

\subsection{Conflicts}

The World Bank report showed that more than 1.5 billion people live in countries affected by violent conflict. Conflict is a push factor for trafficking, migration and poverty. In Nigeria prone conflict zone, Boko Haram trafficked children and use them as soldiers and militias. They kidnapped young girls, sell them into slavery and forcefully married them. Boko Haram, is recruiting and using child soldiers as young as 12-years-old, as well as abducted women and girls in the northern region of Nigeria, some of whom it later subjected to domestic servitude, forced labor, and sex slavery through forced marriages to its militants (Adepelumi,2015).

\subsection{Weak Legal System}

Porous borders, corrupt Government officials, the involvement of international organized criminal groups or networks and limited capacity of our commitment by immigration and law enforcement officers to control borders are contributory factors to human trafficking in Nigeria.

\subsection{Lack of Adequate Legislation and of Political Will}

Lack of adequate legislation and of political will and commitment to enforce existing legislation or mandates are other factors that facilitate trafficking in persons. The Government of Nigeria maintained strong anti-trafficking law enforcement efforts. The 2003 Trafficking in Persons Law Enforcement and Administration Act, amended in 2005 to increase the penalties for trafficking offenders, prohibits all forms of human trafficking. The law prescribes penalties of five years' imprisonment or a fine not to exceed the equivalent of approximately $\$ 645$ or bothfor labour trafficking offenses. These penalties are not sufficiently stringent, because the law allows convicted offenders to pay a fine in lieu of prison term for labour trafficking or attempted trafficking offenses. The law prescribes penalties of 10 to 15 years' imprisonment for sex trafficking offenses or a fine of the equivalent of approximately $\$ 1,250$, or both. For sentences that include only a fine, penalties are not (Adepelumi, 2015).

Human trafficking had become a major source of concern to all societies in recent time. Human trafficking has put Nigeria on the map of the notorious. The problem has assumed wider dimensions not only to the individual traffickers, but also to the country and societies at large. This problem of human trafficking among Nigerians has called for a search of immediate solution as the traffickers have destroyed the image of the nation (Nigeria) among the comity of nations. Human trafficking leads to shade business which is a crime against humanity (Ajagun, 2012).

\subsection{Implications of Human Trafficking in Nigeria}

It has been observed that the victims of human trafficking are not permitted to leave upon arrival at their destination. They are held against their will through acts of coercion and forced to work or provide, services to the traffickers (pimps/madams) whose services may be by bonding, forced labour to commercialized sexual exploitation. In addition, the arrangement may be structured as a work contract, but with no or low payment or in terms which are highly exploitative. Also, in some cases the arrangement is structured as debt bondage, with the victim not being permitted or able to pay off the debt. All the acts above are infringements to human rights of persons as spelt out in Nigeria Constitution of 1999, chapter 4, section 30 which states that: every Nigerian have the right to life which the traffickers violates by the use of physical coercion that sometimes leads to death; 
Persons rights to personal liberty, which the traffickers deprived victims from enjoying through the forced labour and the rights to freedom of movement, which are been deprived, except approved to do so by their pimps/madams (Ajagun, 2012).

\subsection{Trafficked Victims}

Trafficking victims from Nigeria are exposed to psychological problems such as: social alienation both in home and host countries, stigmatization, social exclusion, and intolerance to make reintegration into their local communities difficult. The above are infringements to human rights of Nigerians which violates 1999 constitution, chapter 4 section 30 that: Nigerians must have the rights to freedom of thought, conscience; rights to freedom of movement; rights to freedom of expression; rights to property; rights to private and family life which the victims cannot enjoy both at homes and abroad.

\subsection{Sex Trafficking}

Sex trafficking is a type of violence perpetrated on women that takes place in diverse settings and usually involves many different actors. It is an aspect of human trafficking that is becoming pandemic in society and possibly, the fastest growing human rights violation in the world today. It has generated a lot of concern worldwide and especially in Nigeria where it is very rampant. Sex trafficking in females resembles the ancient dehumanizing slave trade. In most cases, it involves involuntary servitude and is therefore commonly referred to as modern day slavery. Sex trafficking thrives and goes on with impunity because several countries do not have tough anti-trafficking legislation in place and even when there are legislation in place, such laws are often not enforced to check the menace of sex trafficking due mainly to very influential people involved in this disgraceful act (Nnadi,2013).

Sex trafficking involves international agents and brokers who arranged travel and job placement for women from Nigeria. These women who are the victims are lured to accompany traffickers based on promises of lucrative opportunities unachievable in Nigeria. They fell as victims to these deceits because of high level of inflationary trends in the society, acute unemployment, and high poverty rate in the country which majorities of Nigerians found themselves and in which the leaders both at the Federal and State levels had never been conscious enough to address.

It is disheartening to know that once these women (victims) reached their destinations, the women discover that they have been deceived and learn the true nature of work that they will be expected to do. To some extent, many of the women were deceived with lies regarding the financial arrangements and conditions of their employment, later to find themselves in coercive or abusive situation form which escape is both difficult and dangerous to these women (Kara, 2009).

\subsection{Child Labour}

Child labour which is hazardous to the physical, mental, spiritual, moral, or social development of children in Nigeria can interfere with their education. These are infringements to human rights of the Nigerian children who are expected to acquire free and compulsory primary education at the expense of various Federal/ State Governments in Nigeria (Ajagun, 2012). Child slavery is the sale of any person under the age of 18 for monetary gains by the traffickers. This act violates 1999 constitution of the Federal Republic of Nigeria, chapter 4, section 30 which states that: every Nigerian child has the right to life; right to freedom and access to education.

\subsection{Bonded Labour (Debt bondage)}

Bonded labour or debt bondage, is the least known. It is the least known form of labour trafficking today, and yet it is the most widely used methods of enslaving people. Victims become bonded labourers when there is demand as a means of repayment for a loan or service in which its terms and conditions have not been defined or in which the value of the victims' services as reasonably assessed is not applied towards the liquidation of the debt. The value of their work is greater than the original sum of money "borrowed" (Ajagun, 2012).

\subsection{Conclusion}

Trafficking in persons has become the largest manifestation of slavery in present times, depriving people of their rights and fundamental freedoms. It is a threat to global development, safety, and peace. Indeed trafficking is harmful to the individual trafficked as well as to society at large. This paper has outlined the various ways human trafficking in Nigeria has violated human rights of the citizens. The paper examined the trends of human trafficking, contributory factors, implications of human trafficking and recommendations to curb the ugly trend. 


\subsection{Recommendations}

Nigeria became one of the 117 countries signatories of the Trafficking Protocol that came into force on December 25, 2003 by the United Nations at Palemo, Italy. The Protocol is to prevent, suppress and punish "trafficking in persons, especially women and children”.

- The legislations on human trafficking should be made severe and drastic to offenders.

- The governments should address the issue of massive unemployment and poverty in Nigeria.

- Nigeria governments should create enabling environments for entrepreneurship for the citizens.

- Both at national and state level government through the offices of wife of President and wives of the State governors to embark on various programs that aimed to mobilized state and non-state actors to eradicate human trafficking by reducing both the vulnerability of potential victims and the demand for exploitation in all its forms.

- To ensure adequate protection and support to those who fall victim, and supporting the efficient prosecution of the criminals involved, to respect the fundamental human rights of all persons in Nigeria.

\section{References}

Adepelumi, P. (2015). The Root Causes of Human Trafficking in Nigeria.African Center for Advocacy \& Human Development, Nigeria.

Ajagun,S.O.(2012). Implications of Human Trafficking for Human Rights: The Case of Nigeria. Global Journal of Human Science, Arts and Humanities.Vol.12, Issue 11. Global Publisher Inc. USA.

Federal Govt. of Nigeria (1999).The Constitution of the Federal Republic of Nigeria. Abuja: Federal Government Press.

Kara, S. (2009). "Sex trafficking: Inside the Business of Modern Slavery. Columbia: Columbia University Press.

ILO/IPEC. (2002). Child Trafficking in Nigeria: The State of theAct. Geneva: ILO/IPEC.

Musikilu M. (2008). Nigeria: Voodoo Aids Human Trafficking. http://www.wunin. Com/news/Nigeria.

NAPTIP: Trafficking in Persons (Prohibition) Law Enforcement and Administration Act,2003 and Child Rights Act, 2003.

National Human Trafficking Resource Center "Labour Trafficking Fact Sheet" National Human Trafficking Resource Center "Labour trafficking fact sheet" http://www.racinedominicans.org/humantrafficking.cfm

Nnadi, I.(2013). Sex Trafficking and Women: The Nigerian Experience. Journal of Politics and Law. Published by Canadian Center of Science

Ogwu U. J. (2002). "Human Trafficking: The Emerging Threats to Nigeria's Security and Development" Keynote Address Delivered at the Federation of International Women Lawyers (FIDA), Women's Day Seminar, Nigerian Institute of International Affairs, Lagos, March, 8

Okeshola, B.F. (2007).“Assessment of Trafficking in Persons, for Labour Purposes in West and Central Africa, especially Children and Women (Nigeria - Cameroon Human Trafficking Assessment)". A Research conducted for National Agency for the Prohibition of Traffic in Persons and Other Related Matters (NAPTIP).

Okeshola, B. F. (2007), Child Labour as a Social Problem in Nigeria. A Paper Presented at the Workshop Organised by NAPTIP, Kano in Collaboration with UNICEF 'D' between 14th August and 16th August .

Shukla, I. C.(2011). Human Trafficking Statistics.Buzzle.Com.(2003), Trafficking in Persons (Prohibition) Law Enforcement and Administrative Act 2003, Abuja.

UNICEF (2010).“Child protection from violence, exploitation and abuse-Trafficking and Sexual.

UNESCO (2006).Human Trafficking in Nigeria: Root Causes and Recommendations. Policy Paper Poverty Series no 14.2 (E) Paris. 